\title{
Pathology Laboratories Staff Workload Evaluation in Turkey: A Survey Study
}

\author{
Türkiye'de Patoloji Laboratuvarlarında Personel İş Yükü \\ Değerlendirmesi: Bir Anket Çalışması
}

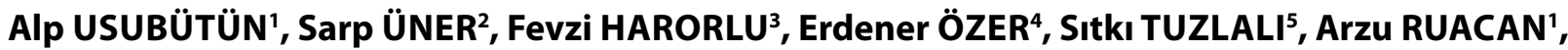 \\ Orhan KOÇ6, Kutsal YÖRÜKOĞLU ${ }^{4}$
}

\author{
Departments of ${ }^{1}$ Pathology and ${ }^{2}$ Public Health, Hacettepe University, Faculty of Medicine, ANKARA, TURKEY, ${ }^{3}$ Department of Pathology, \\ Bursa Ali Osman Sönmez Oncology Hospital, BURSA, TURKEY, ${ }^{4}$ Department of Pathology, Dokuz Eylül University, Faculty of Medicine, IZMiR, TURKEY, \\ ${ }^{5}$ Department of Pathology, Istanbul University, Faculty of Medicine, ISTANBUL, TURKEY, and \\ ${ }^{6}$ Ministry of Health, General Directorate of Treatment Services, ANKARA, TURKEY
}

\begin{abstract}
Objective: The workload affects the quality of the pathology report. The aim of this study was to investigate the territorial distribution and productivity of pathology laboratories around Turkey and to estimate the staff workload.
\end{abstract}

Material and Method: A survey questioning the workload was sent to all Ministry of Health and university hospitals. Staff workload was questioned according to the hospital classification and educational activity to evaluate the productivity. Data were entered using SPSS 16.0 statistical software package program and the distribution criteria, t-test and one-way anova were used in the analysis to evaluate the differences between the averages.

Results: An average of 2.8 pathologists worked at the pathology laboratories. A total of 5.500 biopsies and 3.750 cytology specimens were received and 20.000 blocks prepared per year. Pathologists evaluated 1.935 biopsies and 1.400 cytology specimens on average and this is equivalent to 2.718 biopsies per year. Gynecology and general surgery department materials constituted 57 percent of all biopsies. Each technician prepared 6.200 blocks, 11.500 slides and 1.000 immunohistochemistry preparations on average. An average of 3.4 paraffin blocks was prepared for each biopsy. The efficiency was low in $17 \%$ of teaching hospitals and $77.8 \%$ of non-teaching hospitals. In contrast $62.5 \%$ of teaching hospitals had work overload. The majority $(70.5 \%)$ of the respondents mentioned staff shortage.

Conclusion: There is no pathologist shortage in Turkey and the problem is workload distribution. Pathology residents' overwork would be reduced by using pathology assistants. There is no shortage of technicians or secretaries, but uneven distribution. Pathology staff planning must be tailored taking into account the features of each hospital. Standard planning for all hospitals is not suitable.

Key Words: Pathology, Laboratories, Staff workload, Quality control

Received : 24.09 .2010

Accepted : 11.11 .2010

\section{ÖZ}

Amaç: Çalıșanları iş yükü, patoloji raporunun kalitesini etkiler. $\mathrm{Bu}$ çalışmanın amacı, Türkiye'de kamu hastanelerinde patoloji laboratuvarlarının ülke genelindeki dağılımlarını, verimliliklerini ve laboratuvarlarda çalışan personelin iş yüklerini ortaya koymaktır.

Gereç ve Yöntem: Sağlık Bakanlığı ve üniversitelere bağlı tüm patoloji laboratuvarlarına iş yüklerini sorgulayan bir anket formu posta yolu ile gönderilmiştir. Personel iş yükleri, hastane sınıfları, asistan eğitimi olan ve olmayan kurumlara göre değerlendirilmiş, verimsiz laboratuvarlar saptanmaya çalıșılmıştır. Veriler SPSS 16.0 istatistik paket programı aracılığıyla girilmiş ve analizlerde dağılım ölçütleri ve ortalamalar arası farkı değerlendirmek için t-testi ve tek yönlü varyans analizi kullanılmıștır.

Bulgular: Laboratuvarlarda ortalama 2.8 patolog çalıșmakta, ortalama 5.500 biyopsi, 3.750 sitolojik örnek gelmekte, 20.000 blok yapılmaktadır. Patolog başına yılda ortalama 1.935 biyopsi, 1.400 sitoloji ve toplamda 2.718 biyopsi eşdeğeri iş düşmektedir. Tüm biyopsilerin \%57'sini jinekoloji ve genel cerrahi bölümleri göndermektedir. Bir teknisyen yılda ortalama 6.200 blok, 11.500 preparat ve 1.000 immünohistokimyasal inceleme yapmaktadır. Biyopsi başına blok oranı 3,4'dür. Eğitim kurumlarının \%17,5, hizmet hastanelerinin $\% 77.8$ 'i verimsiz, eğitim hastanelerinin $\% 62,5$ 'i aşırı yüklü çalışmaktadır. Kurumların \%70,5'i en az bir meslek grubunda eksiklik beyan etmiştir.

Sonuç: Türkiyede belirgin patolog açığı saptanmamıştır. Ancak patolog iş yükünün kurumsal dağılımında sorunlar vardır. Asistanların iş yükü "makroskopi teknisyenleri" gibi yeni kadrolar oluşturularak aşılmalıdır. Patoloji teknisyenleri ve sekreterler için de eksiklikten çok dağılım ve verimlilik sorunu vardır. Ancak planlamanın tüm ülke laboratuvarları için standart biçimde değil, mutlaka her hastanenin kendi özelliklerine göre yapılması gerekir.

Anahtar Sözcükler: Patoloji, Laboratuvar, Personel iş yükü, Kalite kontrol

Correspondence: Alp USUBÜTÜN

Department of Pathology, Hacettepe University, Faculty of Medicine, ANKARA, TURKEY

E-mail: usubutuna@yahoo.com Phone: +90 3123051563 


\section{INTRODUCTION}

The pathology report guides the patient's treatment and therefore has a direct effect on the survival and prognosis. The pathology report is the final result of all the procedures performed at an anatomic pathology laboratory. There are many factors that influence this process and therefore the quality of the pathology report. One of these factors is the workload of the anatomic pathology laboratory and its staff. It is important for a laboratory to produce pathology reports in a "high quality" manner, at reasonable cost, and on time. This requires an adequate number of laboratory staff. A very crowded laboratory will be less efficient and cost more while an understaffed laboratory may lead to decreased report quality. The aim should therefore be to produce a maximum quality report with adequate staff.

There are a few studies, mostly from the U.K. and U.S.A., on the optimum number of staff to produce a pathology report in pathology laboratories. There has also been a recent study from Turkey by sending a survey form to a limited number of laboratories $(1,2)$.

The aim of this study was to determine the distribution across Turkey, efficiency and staff (pathologist, technician, secretary) workload of state pathology laboratories.

\section{MATERIAL and METHOD}

The universe of this descriptive study consisted of all pathology laboratories at the Ministry of Health and university hospitals. No sample was chosen and we tried to reach all laboratories.

The survey prepared by the investigators was sent by post by the Ministry of Health to all Ministry hospitals and university pathology laboratories.

${ }^{\star} \mathbf{B}+\mathbf{S}$ : The number of adult autopsies is very low in Turkey and this procedure is only performed at certain centers. We therefore used the biopsy and cytology numbers for the workload. We accepted two biopsies as equal to three cytologies and obtained a value by adding the biopsy and cytological investigation values.

\section{Staff workload calculation}

1- Hospitals are evaluated according the procedure and principles determined by the Ministry with the State Hospitals Association Draft Law and classified into 5 groups as A, B, C, D and E. The Ministry of Health hospitals included were in group A, B or C. The A1 and A2 groups contain training hospitals and some service hospitals while all $\mathrm{B}$ and $\mathrm{C}$ group hospitals are service hospitals in the Ministry of Health classification. The staff workload was evaluated according to this classification.
2- Resident training was used as a factor in calculating staff workload and laboratories with and without resident training were evaluated in two separate groups. According to the data from the U.K., optimum workload for a pathologist is 4.000 biopsies or 6.000 cytologies per year and half of this number (2.000 biopsies or 3.000 cytologies) should be valid for training hospitals (3). We therefore accepted that pathologists could undertake 1.750-2.250 "B+S" investigations per year in institutions with resident training. Laboratories with less than 1.750 " $\mathrm{B}+\mathrm{S}$ " investigations per year were considered inefficient and those with more than 2.250 " $\mathrm{B}+\mathrm{S}$ " investigations per year indicated excessive pathologist workload with a resultant decrease in quality. We similarly accepted that pathologists working at institutions without resident training could undertake 3.500-4.000 " $\mathrm{B}+\mathrm{S}$ " investigations per year. Laboratories where there was less than 3.500 " $\mathrm{B}+\mathrm{S}$ " investigations per pathologist were considered inefficient and those with more than 4.000 " $\mathrm{B}+\mathrm{S}$ " investigations per pathologist per year indicated excessive pathologist workload with a resultant decrease in quality.

The data were entered into the SPSS 16.0 statistical package software and the t-test and one-way variance analysis were used to evaluate the distribution criteria and differences between the means during analyses.

\section{RESULTS}

A total of 261 hospitals consisting of 35 (13.4\%) university, 41 (15.7\%) Ministry of Health training and 185 (70.9\%) Ministry of Health service hospitals were included in the study. Pathology resident training was provided in $28(80 \%)$ of the university hospitals and 14 (34.1\%) of the Ministry of Health training hospitals. Data was collected on a total of 758 pathologist in the study with 185 from universities and 553 from the Ministry of Health hospitals. The number of technicians was reported from 247 institutions for a total of 785 and the number of secretaries was reported from a total of 198 institutions for a total of 346.

The number of biopsies was reported from 243 institutions for a total of 1.339 .998 per year and the number of cytology investigations was reported from 216 institutions for a total of 816.097 per year. The number of blocks was reported from 230 institutions for a total of 4.743 .484 per year and the number of slides was reported from 233 institutions for a total of 8.154 .715 per year.

We queried the general percentage distribution of the specialties sending material to the pathology laboratory and the materials themselves. This section was answered by 199 hospitals and the distribution was obstetrics and gynecology 
departments $29.8 \%$, general surgery departments $27.6 \%$, urology departments $7.13 \%$, plastic and reconstructive surgery departments $6.23 \%$ and dermatology departments $4.47 \%$ for the first five places.

Table I presents the frequency distribution measures for the pathology laboratories that participated in the study regarding the institution, workforce and activities. The mean number of beds for the participating hospitals was 356 (14 - 2.200). The number of surgical operations performed was close to 11 thousand on average $(1-79.836)$. The mean number of specialists working at pathology laboratories was $2.8( \pm 2.6)$ and the median number was 2 (1-15). Resident training was provided at 42 institutions. A mean number of $3.0( \pm 3.0)$ technicians worked at the laboratories and there were 14 laboratories with no technicians. The mean numbers for the participating laboratories were over 5.000 biopsies (243 laboratories), over 3.750 cytologies (216 laboratories), over 280 frozen sections (106 laboratories), over 20.000 blocks (230 laboratories) and over 40.000 slides (233 laboratories) (Table I). The ratio of slides to blocks was 2.2 on average with a maximum of 17 .

We queried staff shortages in pathology laboratories in the study. There were 221 institutions that evaluated the adequacy of the number of pathologists and 47 (21.3\%) reported a shortage while the same numbers were 199 and $90(45.2 \%)$ for technicians and 168 and 84 (50\%) for secretaries, respectively. There were 132 institutions that evaluated the numbers of all three groups and $70.5 \%$ stated there was shortage of at least one occupational group. There were 40 institutions that provided resident training and evaluated the adequacy of the number of residents and 21 (52.5\%) felt the number was inadequate.
Table II presents the frequency distribution measures of the annual activity per member of staff in the pathology laboratories participating in the study. The mean annual numbers per pathologist in the participating laboratories were 1.935 biopsies, 1.400 cytologies, 2.718 " $\mathrm{B}+\mathrm{S}$ ", more than 55 frozen sections and more than 800 IHCs. The technician workload at these laboratories were more than 6200 blocks, almost 11.500 slides and more than 1.000 IHCs (Table II). The number of biopsies per block reached over in some laboratories 20 but the mean number was 3.4

Table III and Table IV present the frequency distribution measures of the annual activities per member of staff in the pathology laboratories participating in the study by hospital. Analysis of the annual activities by pathologist in the pathology laboratories participating in the study according to hospital classification revealed that the workload in B and C groups that consisted entirely of service hospitals was lower than in group A hospitals and universities. The difference between the groups was statistically significant except for cytologies $(\mathrm{p}<0.05)$. Analysis of the annual activities by technician in the pathology laboratories participating in the study according to hospital classification revealed that the workload in B and $\mathrm{C}$ groups that consisted entirely of service hospitals was lower than in group A hospitals and universities. The difference between the groups was statistically significant when the number of blocks and slides was analyzed by group ( $\mathrm{p}<0.05)$.

Table $\mathrm{V}$ presents the frequency distribution measures and the differences for some features of the institutions when they were divided into two as those that provided and did not provide resident training. The numbers for pathologist and technician, annual biopsies, cytologies, blocks and

Table I: Factors describing the frequency distribution of the institution, workforce and activity features of the pathology laboratories participating in the study (2009)

\begin{tabular}{|l|l|r|r|r|r|r|r|}
\multicolumn{2}{c|}{} & \multicolumn{1}{c|}{$\mathbf{n}$} & \multicolumn{1}{c|}{ Mean } & \multicolumn{1}{c|}{ SD } & \multicolumn{1}{c|}{ Median } & Minimum & Maximum \\
\hline \multirow{4}{*}{ Hospital } & Number of beds & 243 & 355,7 & 273,3 & 300 & 14 & 2.200 \\
\hline & Number of surgeries (annual) & 192 & $10.976,8$ & $11.455,7$ & 7.059 & 1 & 79.836 \\
\hline \multirow{4}{*}{\begin{tabular}{l} 
Workforce (number) \\
\cline { 2 - 8 }
\end{tabular}} & Pathologist & 261 & 2,8 & 2,6 & 2 & 1 & 15 \\
\cline { 2 - 8 } & Resident & 42 & 5,4 & 2,9 & 5,5 & 1 & 12 \\
\cline { 2 - 8 } & Technician & 247 & 3,2 & 3,0 & 2 & 1 & 26 \\
\cline { 2 - 8 } & Secretary & 198 & 1,7 & 1,5 & 1 & 1 & 13 \\
\hline \multirow{4}{*}{$\begin{array}{l}\text { Work performed (number } \\
\text { year) }\end{array}$} & Biopsy & 243 & $5.514,4$ & $5.862,4$ & 3.200 & 75 & 43.800 \\
\cline { 2 - 8 } & Cytology & 216 & $3.778,2$ & $4.035,0$ & 2.179 & 60 & 22.016 \\
\cline { 2 - 8 } & Frozen & 106 & 287,5 & 453,9 & 104,5 & 1 & 2.400 \\
\cline { 2 - 8 } & Block & 230 & $20.623,8$ & $28.035,3$ & 10.596 & 200 & 250.000 \\
\cline { 2 - 8 } & Slide & 233 & $40.149,0$ & $62.745,3$ & 18.000 & 300 & 500.000 \\
\hline
\end{tabular}


Table II: Descriptive measures of the annual workload frequency distribution per staff member at the pathology laboratories participating in the study (2009)

\begin{tabular}{|c|c|c|c|c|c|c|c|}
\hline & & $\mathbf{n}$ & Mean & SD & Median & Minimum & Maximum \\
\hline \multirow{7}{*}{ Annual number per pathologist } & Biopsy & 243 & $1.933,2$ & $1.024,5$ & 1.733 & 75 & 7.500 \\
\hline & Cytology & 216 & $1.400,8$ & $1.181,0$ & $1.069,3$ & 60 & 7.500 \\
\hline & $\mathrm{B}+\mathrm{S}^{\star}$ & 247 & $2.718,5$ & $2.482,7$ & $1.359,2$ & 121,7 & 7.500 \\
\hline & Frozen & 106 & 56,3 & 28,9 & 79,1 & 0,5 & 585 \\
\hline & Block & 230 & $6.283,9$ & $5.186,7$ & $4.016,3$ & 200 & 20.736 \\
\hline & Slide & 233 & $11.450,7$ & $9.353,3$ & $9.011,0$ & 300 & 62.500 \\
\hline & IHC & 82 & 836,7 & 500,0 & 917,3 & 1,5 & $3.833,3$ \\
\hline \multirow{4}{*}{ Annual number per technician } & Block & 221 & $6.230,6$ & $4.500,0$ & $5.710,1$ & 200 & 37.000 \\
\hline & Slide & 221 & $11.494,3$ & $7.800,0$ & $13.028,8$ & 300 & 125.000 \\
\hline & IHC $^{* *}$ & 80 & $1.053,4$ & 500,0 & $2.629,2$ & 10,0 & 23.000 \\
\hline & Biopsy & 232 & 1.089 & $1.172,7$ & 800 & 35 & 8.731 \\
\hline Annual number per secretary & Biopsy & 186 & 2.133 & 2.034 & 1.552 & 50 & 13.125 \\
\hline Pathologist/Technician ratio & & & 1,2 & 0,67 & 1 & 0 & 5 \\
\hline
\end{tabular}

*Value obtained by combining biopsy and cytology investigations in workload calculation (see "Material and Methods").

** Immunohistochemical study.

Table III: Frequency distribution measures of annual activities per pathologist in the pathology laboratories participating in the study and its distribution by hospital classification (2009)

\begin{tabular}{|c|c|c|c|c|c|c|c|c|}
\hline Annual number per pathologist & Hospital classification & $\mathbf{n}$ & Mean & SS & Minimum & Maximum & $\mathbf{F}$ & $\mathbf{p}$ \\
\hline \multirow{4}{*}{ Biopsy } & A1 & 36 & $2.026,6$ & 809,1 & 598 & 3.826 & 2,98 & 0.032 \\
\hline & A2 & 86 & $2.168,8$ & $1.304,1$ & 290 & 7.500 & & \\
\hline & $B$ and $C$ & 79 & $1.714,2$ & 837,1 & 75 & 5.000 & & \\
\hline & University & 33 & $1.849,2$ & 761,4 & 300 & 3.111 & & \\
\hline \multirow{4}{*}{ Cytology } & A1 & 35 & $1.683,2$ & 794,9 & 176 & 5.471 & 2,56 & 0.056 \\
\hline & A2 & 67 & $1.582,9$ & $1.304,0$ & 290 & 7.500 & & \\
\hline & $B$ and $C$ & 74 & $1.185,9$ & 834,7 & 75 & 5.000 & & \\
\hline & University & 33 & $1.145,3$ & 742,12 & 300 & 3.111 & & \\
\hline \multirow{4}{*}{$B+S^{*}$} & A1 & 36 & $3.073,8$ & $1.411,5$ & 667 & 6.764 & 4,27 & 0.006 \\
\hline & A2 & 86 & $2.991,0$ & $1.536,1$ & 714 & 7.500 & & \\
\hline & $B$ and $C$ & 82 & $2.357,1$ & $1.193,8$ & 122 & 7.333 & & \\
\hline & University & 34 & $2.515,1$ & $1.028,2$ & 417 & 5.000 & & \\
\hline \multirow{4}{*}{ Bloc } & A1 & 36 & $7.368,3$ & $4.415,4$ & 917 & 16.875 & 8,99 & $<0.001$ \\
\hline & A2 & 80 & $6.557,7$ & $4.187,0$ & 500 & 20.736 & & \\
\hline & $B$ and $C$ & 72 & $4.654,9$ & $3.154,7$ & 200 & 17.500 & & \\
\hline & University & 33 & $8.480,5$ & $3.639,7$ & 450 & 16.667 & & \\
\hline \multirow{4}{*}{ Slide } & A1 & 35 & $16.255,7$ & $11.720,2$ & 3.333 & 62.500 & 11,25 & $<0.001$ \\
\hline & A2 & 84 & $10.869,1$ & $9.618,3$ & 1.000 & 50.000 & & \\
\hline & $B$ and $C$ & 72 & $7.872,6$ & $5.475,3$ & 300 & 30.000 & & \\
\hline & University & 33 & $16.116,7$ & $7.189,4$ & 4.156 & 30.000 & & \\
\hline \multirow{4}{*}{ Frozen } & A1 & 35 & 71,9 & 112,9 & 5 & 585 & 4,61 & 0.005 \\
\hline & A2 & 30 & 19,7 & 30,4 & 0,5 & 147 & & \\
\hline & $B$ and $C$ & 10 & 23,9 & 44,8 & 2 & 150 & & \\
\hline & University & 30 & 79,5 & 49,0 & 20 & 212 & & \\
\hline \multirow{4}{*}{$\mathrm{IHC}^{* *}$} & A1 & 28 & 683,8 & 759,9 & 14 & 3.333 & 6,59 & 0.001 \\
\hline & A2 & 20 & 574,1 & 732,7 & 17 & 3.333 & & \\
\hline & $B$ and $C$ & 6 & 102,5 & 195,4 & 1,5 & 500 & & \\
\hline & University & 26 & $1.414,5$ & $1.050,7$ & 60 & 3.833 & & \\
\hline
\end{tabular}

* Value obtained by combining biopsy and cytology investigations in workload calculation (see "Material and Methods").

** Immunohistochemical study. 
slides, the annual block and slides per technician and the number of hospital beds were higher in the hospitals with resident training than in those without resident training and the difference was statistically significant $(\mathrm{p}<0.001)$. We found no difference between the groups for " $\mathrm{B}+\mathrm{S}$ " and "slide-block ratio" variables (Table V).

Table VI presents the comparison of the pathologist workload in institutions with and without residency training by work efficiency of the laboratories. Regarding the laboratories with resident training, 7 (17.5\%) were inefficient while some (62.5\%) had work overload. However, $77.8 \%$ of the laboratories in the institutions without resident training were inefficient. The difference in work efficiency between the laboratories in the institutions with and without resident training was statistically significant ( chi-square $=56.6 ; \mathrm{p}<0.001$ ).

\section{DISCUSSION}

The workload of a laboratory and its staff have a direct influence on the production of a high quality pathology report. Staff costs make up 50-70\% of the total costs of a clinical laboratory (3). It is obvious that the laboratory needs to have an optimum number of staff to produce a high/quality and cost effective product. There are significant changes between the reference numbers provided for laboratories in studies on staff workload (3). It is therefore

Table IV: Frequency distribution measures of annual activities per technician in the pathology laboratories participating in the study and its distribution by hospital classification (2009)

\begin{tabular}{|l|l|r|r|r|r|r|c|c|}
\hline Annual number per technician & Hospital classification & \multicolumn{1}{|c|}{ n } & \multicolumn{1}{c|}{ Mean } & \multicolumn{1}{c|}{ SD } & Minimum & Maximum & F & p \\
\hline Block & A1 & 35 & $9.307,3$ & $7.361,3$ & 550 & 33.750 & 9.44 & $<0.001$ \\
\hline & A2 & 79 & $5.973,8$ & $5.221,9$ & 500 & 31.104 & & \\
\hline & B and C & 66 & $3.999,4$ & $2.901,6$ & 200 & 150.000 & & \\
\hline & University & 33 & $8.540,6$ & $7.257,7$ & 500 & 37.000 & & \\
\hline Slide & A1 & 34 & $20.090,9$ & $21.025,8$ & 3.667 & 125.000 & 10.97 & $<0.001$ \\
\hline & A2 & 81 & $9.655,4$ & $9.493,4$ & 1.000 & 66.667 & & \\
\hline & B and C & 65 & $6.918,8$ & $5.738,3$ & 300 & 27.686 & & \\
\hline & University & 33 & $16.670,8$ & $15.844,9$ & 4.156 & 87.500 & & \\
\hline IHC $^{\star}$ & A1 & 27 & 844,5 & $1.017,5$ & 10 & 4.059 & 1.50 & 0.21 \\
\hline & A2 & 20 & 480,9 & 574,2 & 25 & 2.500 & & \\
\hline & B and C & 5 & 218,8 & 436,9 & 10 & 1.000 & & \\
\hline & University & 26 & $19.32,5$ & $4.379,6$ & 30 & 23.000 & & \\
\hline
\end{tabular}

* Immunohistochemical study

Table V: Frequency distribution of some features of participating pathology laboratories by the presence or absence of residency training (2009)

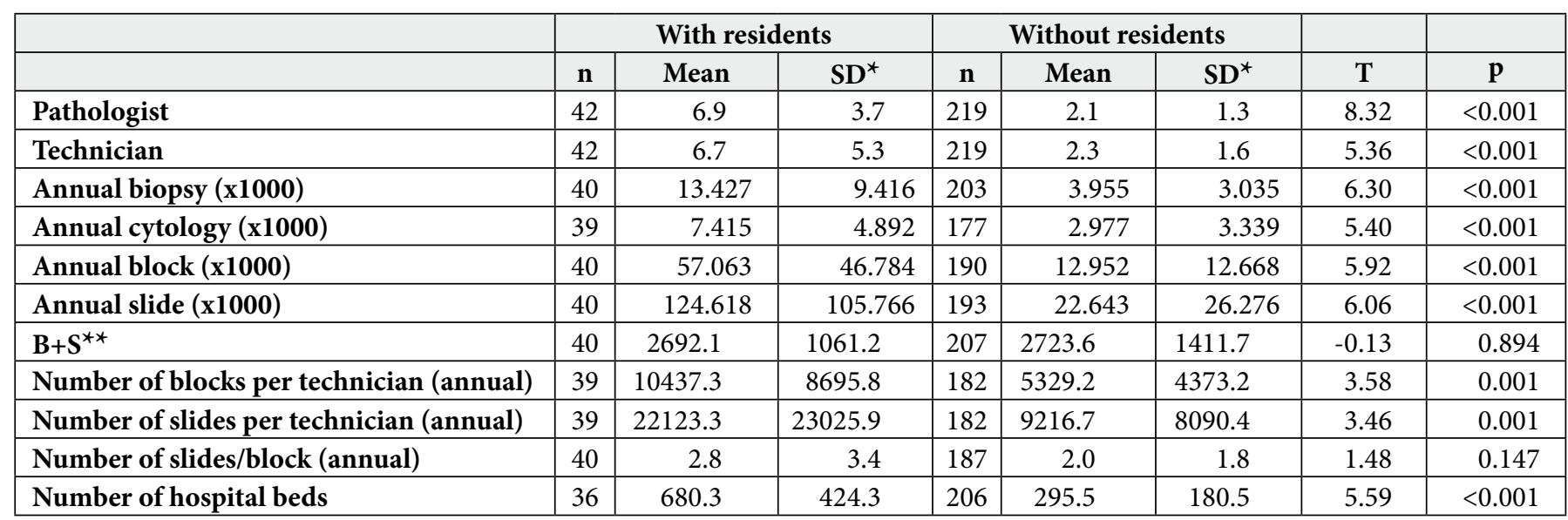

* Standard deviation

** Value obtained by combining biopsy and cytology investigations for workload calculation (see Material and Methods). 
Table VI: Comparison by laboratory efficiency of pathologist workload in institutions with and without resident training (2009)

\begin{tabular}{|c|c|c|c|c|c|c|c|c|}
\hline \multirow{3}{*}{ Laboratory } & \multicolumn{4}{|c|}{ Institution } & & & & \\
\hline & \multicolumn{2}{|c|}{ With resident training } & \multicolumn{2}{|c|}{ Without resident training } & \multicolumn{2}{|c|}{ Total } & & \\
\hline & n & $\%^{*}$ & $\mathbf{n}$ & $\%^{*}$ & $\mathbf{n}$ & $\%^{*}$ & Chi square & $\mathbf{p}$ \\
\hline Low efficiency & 7 & 17.5 & 161 & 77.8 & 168 & 68.02 & 56.6 & $<0.001$ \\
\hline Efficient & 8 & 20.0 & 14 & 6.8 & 22 & 8.91 & & \\
\hline Excessive workload & 25 & 62.5 & 32 & 15.4 & 57 & 23.08 & & \\
\hline
\end{tabular}

* column percentage

difficult to define absolute standards for all laboratories. However, it is also important to plan according to the country's finances. We were able to evaluate $73.7 \%$ of the pathologists in Turkey within the context of this study.

Pathology laboratories differ from other clinical laboratories with their different and variable workload and it is difficult to calculate this workload in pathology laboratories (4). The number of biopsies is an important parameter but it does not fully reflect the pathologist's workload as the time allocated to each specimen is different. Methods that can calculate the workload in detail while taking into account the time and labor required for each material have therefore been suggested (5-9). Such a detailed method is only possible when the data is used with suitable computer software. However, one must not forget that there is no widely accepted method (9-11). Our study is also limited that it has not taken the qualifications of pathology laboratories into account.

Despite the margin of error, calculating the workload by taking the number of biopsies into account therefore becomes the most practical method for Turkey under current conditions. This assumes that 4.000 biopsies, 6.000 cytologies ( 1 biopsy equals 1.5 cytologies) or 600 autopsies represent equal workload at hospitals without training while half these numbers are suggested for hospitals with training (5). Adult autopsies are nonexistent or very few in number in Turkey and we have therefore calculated workload by using biopsy and cytology numbers only. Each pathologist in Turkey has a workload equivalent to an average of 2.718 biopsies per year. Considering that most pathologists work for the Ministry of Health service hospitals, there is no significant need for more pathologists in Turkey with a rough calculation.

Demographics-based models that give a rate per 100.000 population or metric-based models that contain measurable parameters may be used when determining the number of pathologists (12). The demographics-based model indicates
1.7 to 5.2 pathologists per 100.000 population in different countries $(9,12)$. There are 27 pathologists per 1 million population in European countries while Turkey has the smallest number of pathologists in Europe (13). One would expect Turkey to have approximately 2.025 pathologists judging by the European average. However, the fact that there are almost no adult autopsies in Turkey (14) and the lack of cervical screening programs decreases the workload of pathologists compared to developed countries. One must also take into account conditions specific to Turkey such as not sending all samples to pathology, not performing tissue sampling even when necessary, the inability of patients to get to hospitals due to poor socioeconomic condition, and a lack of awareness regarding where and how to access pathology services.

The Turkish Workforce Report prepared by the Ministry of Health and the Council of Higher Education states that a total of 855 pathology residencies became available between 2002 and 2007 (15). There are currently about 1.000 pathologists in Turkey. The pathology resident rate is $25 \%$ on average in European countries and $31 \%$ in Turkey according to 2002 data (15). This indicates that the number of pathologists per population is increasing. These data should be taken into account when planning the number of pathologists in Turkey so that work overload is avoided.

There are serious problems with the institutional distribution of the pathologist workload in Turkey. The mean number of annual cases for pathologists working at service hospitals in Turkey is 2.723 (the optimum number is 4.000). However, the same number is 2.692 in training hospitals and it is above the recommended limit of 2.000 biopsies. Comparison of various data has indicated that pathologists evaluate 3.700 cases on average and that this number may increase to 6.500 in centers with biopsy numbers over 50.000 (there are technicians who obtain the macroscopic material in some centers) (16). Comparison with the standards reveals that $78 \%$ of the service hospitals are inefficient while $63 \%$ of training hospitals have excessive 
workload. Pathology residents being trained at the Ministry of Health training hospitals state that they are not happy with their training and that the main responsible factor is the workload (17). These results indicate that the workload is high in training hospitals while the Ministry of Health hospitals with a much smaller number of cases are not used efficiently. Studies have shown that the number of cases received at a pathology laboratory is an important parameter defining the efficiency of the pathologist and that laboratories with an annual case number of 20.00030.000 are the most efficient (16).

Is it possible to determine a standard number for members of staff at pathology laboratories according to the population or number of beds? Our study indicates that planning number of pathologists solely by the number of hospital beds or the population leads to incorrect results. Using the demographics-based model for calculations may reveal the number of pathologists required for the whole country but using standard planning for all hospitals will lead to marked errors in the results (12). Pathology is a specialized field and the workload is defined by clinicians. For example, centers with oncological surgery have more need for biopsies and patients go to these centers for treatment. The workload can be different even in two universities with similar numbers of biopsies (7). Canada, with a developed and well planned healthcare system, also has an almost 20-fold difference per population in different regions (one pathologist per 6.316106.667 persons) (9). One must therefore take the hospital features into account when planning.

Pathology residency training is outside the scope of this article but we need to emphasize some of our data. Most $(30 \%)$ of the material evaluated at pathology departments in Turkey consist of gynecological specimens. Material from general surgery, urology, plastic surgery and dermatology (in order of frequency) make up $75 \%$ of the samples received at the pathology laboratory. These biopsy samples must be seen by residents during residency training and they must have a major place in the training program.

Querying staff shortages, approximately $50 \%$ of the institutions stated they were short of secretaries, technicians and residents. The shortage of "pathology residents" can only be a result of pathologist shortages in the country. Stating a resident shortage in the survey is an indication that residents are used for daily work in that department. The work expected from a resident in a department should be handled by new posts such as "macroscopy technicians". Specially trained macroscopy technicians have been used widely for more than 50 years especially in the U.S.A. and
U.K. to process selected biopsies under inspection and are said to provide enormous benefit $(16,18-21)$. The excessive workload of residents especially at training hospitals in Turkey $(1,17)$ can be decreased with macroscopy technicians, as can be seen in other countries, and the training improved (22). Macroscopy technicians will also help increase the service quality at service hospitals.

Studies on the workload of pathology technicians reveal that they evaluate an average of 2.300-3.000 cases or 8.2009.900 blocks per year and that the technician to pathologist ratio is 1.2 (16). The workload increases with the increased complexity due to the number of cases and technicians may also need to be involved in administrative duties to organize this complexity (16). The survey results demonstrate that an average number of 6.264 blocks are prepared per pathology technician in Turkey but there is also substantial differences between institutions. This number at training hospitals (10.437) is almost twice that at service hospitals (5.329). Histochemical and immunohistochemical methods are used more often at training hospitals and research is also performed. These findings demonstrate that the workload of pathology technicians is increased at training hospitals while they work inefficiently at the Ministry of Health hospitals. Efficiency of technical staff is affected by many factors such as the work arrangement, case reporting duration and the use of technology and the efficiency is said to increase in centers with a biopsy number over 20.000 in general (23). The results indicate that the pathology technician also suffers from a distribution and efficiency problem more than an actual shortage in Turkey.

\section{REFERENCES}

1. Yörükoğlu K, Usubütün A, Doğan Ö, Önal B, Aydın Ö: Türkiye’de patoloji laboratuarlarının genel profili. Turk Patoloji Derg 2009, 25:19-28

2. Yörükoğlu K, Usubütün A, Doğan Ö, Önal B, Aydın Ö: Türkiye’de patoloji laboratuarlarında kalite kontrol. Turk Patoloji Derg 2009, 25:29-37

3. Valenstein PN, Souers R, Wilkinson DS: College of American Pathologists. Staffing benchmarks for clinical laboratories: a College of American Pathologists Q-probes study of staffing at 151 institutions. Arch Pathol Lab Med 2005, 129:467-473

4. Buesa RJ: Histology aging workforce and what to do about it. Ann Diagn Pathol 2009,13:176-184

5. Royal College of Pathologists. Pathology: the science behind the cure. Guidelines on staffing and workload for histopathology and cytopathology departments (2nd ed.) June 2005. Available from: http://www.rcpath.org/resources/pdf/ guidehistocytoworkload0605.pdf

6. Suvarna SK, Kay MS: KU activity: a method for calculating histopathologists' workloads. J Clin Pathol 1998, 51:530-534 
7. Jakić-Razumović J, Tomić S, Karaman I: Comparison of histopathologists' workloads in two pathology departments in Croatia. Croat Med J 2001, 42:188-192

8. Meijer GA, Oudejans JJ, Koevoets JJ, Meijer CJ: Activity-based differentiation of pathologists' workload in surgical pathology. Virchows Arch 2009,454: 623-628

9. Maung RT: What is the best indicator to determine anatomic pathology workload? Canadian experience. Am J Clin Pathol 2005, 123:45-55

10. Winter S, Cox GJ, Corbridge R, Chaplin AJ, Millard PR, Shah $K A$ : Effects of clinical service reorganisation on cellular pathology workload. J Clin Pathol 2004, 57:22-26

11. Carr RA, Sanders DS, Stores OP, Smew FA, Parkes ME, RossGilbertson V, Chachlani N, Simon J: The Warwick system of prospective workload allocation in cellular pathology--an aid to subspecialisation: a comparison with the Royal College of Pathologists' system. J Clin Pathol 2006, 59:835-839

12. Martin SA, Styer PE: Assessing performance, productivity, and staffing needs in pathology groups: observations from the College of American Pathologists PathFocus pathology practice activity and staffing program. Arch Pathol Lab Med 2006, 130:1263-1268

13. Ruiter DJ, Roald B, Underwood J, Prat J: UEMS Section of Pathology/European Board of Pathology. Histopathology training in Europe: a lesson for other specialties? Virchows Arch 2004, 444:278-282

14. Kösemehmetoğlu K, Tümer AR, Usubütün A: Autopsy status and pathologists attitude towards autopsy in Turkey. Turk J Med Sci 2007, 37: 351-358
15. Türkiye Sağlık İnsan Gücü Raporu. Available from: http://www. saglik.gov.tr/TR/Genel/BelgeGoster.aspx?F6E10F8892433CFF1 A9547B61DAFFE2A04A8EB250F0C8474

16. Buesa RJ: Staffing benchmarks for histology laboratories. Ann Diagn Pathol 2010, 14: 182-193

17. Kösemehmetoğlu K, Tan A, Esen T, Eren Ateş K: Asistanların bakışı ile Türkiyede patoloji uzmanlık öğrencisi eğitimi: Bir Anket Çalışması. Turk Patoloji Derg 2010, 26: 95-106

18. Grzybicki DM, Reilly TL, Hart AR, Galvis CO, Raab SS: National practice characteristics and utilization of pathologists' assistants. Arch Pathol Lab Med 2001, 125:905-912

19. Reese JA, Hall C, Bowles K, Moesinger RC: Colorectal surgical specimen lymph node harvest: improvement of lymph node yield with a pathology assistant. J Gastrointest Surg 2009, 13: 1459-1463

20. Grzybicki DM, Vrbin CM, Reilly TL, Zarbo RJ, Raab SS: Use of physician extenders in surgical pathology practice. Archiv Pathol Lab Med 2004, 128: 165-172

21. Duthie FR, Nairn ER, Milne AW, McTaggart V, Topping D: The impact of involvement of biomedical scientists in specimen dissection and selection of blocks for histopathology: a study of time benefits and specimen handling quality in Ayrshire and Arran area laboratory. J Clin Pathol 2004, 57: 27-32

22. Grzybicki DM, Vrbin CM: Pathology resident attitudes and opinions about pathologists' assistants. Archiv Pathol Lab Med 2003, 127: 666-672

23. Buesa RJ: Productivity standards for histology laboratories. Ann Diagn Pathol 2010, 14: 107-124 